\title{
Paweł Hulka-Laskowski - stavitel mostů mezi národy
}

\author{
Libor Martinek (Opava - Wrocław)
}

\begin{abstract}
Abstrakt
Z polského Žyrardova pocházející spisovatel, překladatel a propagátor česko-polských literárních a kulturních vztahů Paweł Hulka-Laskowski (1881-1946) byl jedním z těch, kteři v atmosféře konfliktů na pohraničí na konci třicátých let dvacátého století, kdy vzájemné neprátelství mezi Čechy a Poláky rozpoutaly vlády obou zemí, hledali objektivní pravdu o národní povaze Poláků a Čechů, stavěli mosty, které by pomohly sousedící národy spojit společnou prací, výměnou myšlenek, interakcí kultur. Článek si kromě literárněvědného aspektu klade za cíl připomenout čtenářům dílo a aktivity tohoto u nás pozapomenutého polského spisovatele s českými kořeny, spojovaného především s prekladem Haškových Osudů dobrého vojáka Švejka za světové války do polštiny.
\end{abstract}

\section{Klíčová slova}

Paweł Hulka-Laskowski; polská literatura; česká literatura; překlady; interakce kultur; pohraničí

\section{Abstract \\ Paweł Hulka-Laskowski - Builder of Bridges between Nations}

From the Polish Żyrardów coming writer, translator and promoter of Czech-Polish literary and cultural relations Paweł Hulka-Laskowski (1881-1946) was one of those who in an atmosphere of conflict on the frontier at the end of the 1930s when the mutual animosity between Czechs and Poles unleashed the governments of both countries to find objective truth about the national character of the Poles and Czechs, built bridges, which would help unite neighboring nations working together, exchanging ideas, interaction of cultures. The article, in addition to the literary aspect, aims to remind the readers of the work and activities of the Czech Republic almost forgotten Polish writer of Czech origin, associated especially with the translation of Hašek's The Good Soldier Švejk and His Fortunes in the World War into Polish.

\section{Keywords}

Paweł Hulka-Laskowski; Polish literature; Czech literature; translation; interaction of cultures; Borderlands 
V našem př́spěvku se chceme zabývat především dílem Pawła Hulky-Laskowského (18811946), méně jeho životem, nebot ten je dnes již dobře zpracován v četných článcích ${ }^{1}$ a také zpřístupněn (zejména žyrardovské období) na internetu. ${ }^{2}$ Nicméně také v př́ípadě díla rodáka ze Žyrardova nás bude zajímat ponejvíce ta jeho část, v níž se odráží jeho vztah k Čechům a jejich kultuře (tedy sféra beletrie, reportáží, publicistiky a překladů) a problematika vzájemných polsko-českých vztahů, která je jednak v jeho díle reflektována a jednak v rámci daného tématu patří do širšího historického, kulturního, politického a společenského kontextu.

V literatuře předmětu se nezřídka setkáváme jak s nedoceněním, tak s přeceněním skutečnosti jeho českého původu. Paweł Hulka byl synem žyrardovského tkalce Józefa Hulky a Elżbiety, rozené Hovorkové. Narodil se do rodiny potomků českých exulantů, kteř́ v důsledku náboženského pronásledování za habsburské protireformace opustili svou vlast a přestěhovali se na polské území. Měl české kořeny, ale nepovažoval se za Čecha, a to ani za zpolštěného. Plně si uvědomoval svou polskou národní prř́slušnost. V jeho literárním díle se nejednou setkáváme s hrdostí na skutečnost, že byl geneticky spojen se skupinou lidí, kteří se $\mathrm{v}$ obraně svobody svědomí a pravdy vlastního přesvědčení odhodlali ke značné oběti emigrace. Dobře to dokumentuje Hulkův článek Spowiedź kalwina zveřejněný v roce 1933 na stránkách časopisu Wiadomości Literackie jako obrana před útoky konzervativních katolických kruhů: „Przodkowie moi po nieszcześliwym powstaniu przeciwko Habsburgom, pobici na Biatej Górze na poczatku wojny trzydziestoletniej, musieli rzucić wszystko i iść na tutaczkę. Znaleźli druga ojczyznę w Polsce. Uczyli mnie wdzięczności dla tej ojczyzny $i$ za krople czeskiej krwi, powiklanej kalwinizmem, staratem sie stużyć swemu spoteczeństwu, jak umiatem. “" $\mathrm{S}$ větší či menší mírou náboženské netolerance se Paweł Hulka setkával zřejmě již od dětství, protože „kalvínem“ ho nazývali jeho vrstevníci; jeho předkové byli př́slušníky jednoty bratrské, tedy církve presbyteriánského typu; Hulka je i v biografické literatuře označován za reformovaného protestanta, odtud tedy jeho označení za příslušníka kalvinistické větve protestantismu. Podruhé se podobně otevřeně vyjádřil ke svému rodokmenu na stránkách Odrodzenia, čímž se eo ipso zapojil do kampaně na obranu Slezska po vzniku samostatného Polska: „Jestem potomkiem wygnańców czeskich pobiatogórskich, którzy jako tutacze w Polsce znaleźli wtóra ojczyznę i serdecznie do niej przylgnelli, nie przestajac jednak ze czcia i mitocia wspominać tych wielkich i szlachetnych przedoków czeskich, którzy pozostawili w Czechach wszystko dla ratowania wolności sumienia. "*4 Hulka se tedy na jedné straně vyjadřoval s hrdostí na téma svých českých předků, pevných ve viře, na straně druhé se cítil Polákem bránícím zájmy své vlasti jako její občan a patriot. V knize vzpomínek Księżyc nad Cieszynem (1946) nacházíme pěkný doklad jeho občanské statečnosti, když mu při výslechu na gestapu byla navržena změna národní př́slušnosti z polské na českou, jinými slovy, aby podepsal volkslistu: „Trzysta lat wrośliśmy

1 Z novějších např. SNOCH, Bogdan: Górnoślaski Leksykon Biograficzny. Suplement do wydania drugiego. Katowice: Muzeum Śląskie, 2006, s. 50-51.

2 http://hulka-laskowski.blog.onet.pl/

3 HULKA-LASKOWSKI, Paweł: Spowiedź kalwina. Wiadomości Literackie, 1933, č. 54, s. 1.

4 HULKA-LASKOWSKI, Paweł: Bracia nasi za Olza i bracia nasi Czesi. Odrodzenie, 1945, č. 33, s. 1-2. 
w Polskę i polskośc. Czeskie pochodzenie jest tylko pochodzeniem. Czeskich przodków szanuje dla ich postawy moralnej wobec ucisku, myśle o nich ze czcia, ale jestem Polakiem."

Pro Hulkovu publicistiku a jeho postoje k Čechům a jejich národní kultuře je charakteristické překrytí dvou vrstev jeho osobnosti - pocit spojení s tradicí české reformace a zároveň polského sebeuvědomění. Zpočátku byl především autodidaktem, pracoval v textilní továrně v administrativě, poté díky stipendiu studoval filozofii na evangelicko-reformované univerzitě v Heidelbergu, vychoval se na vzorech polské národní kultury, ale vyhýbal se provincionalismu, jak o tom svědčí jeho nejen četné publicistické, ale i odborné (filozofické a religionistické), editorské a překladové práce, v beletristice pak převážně čerpal z univerzálních látek a témat. Abychom byli konkrétní, vyjádříme se postupně k tomuto bohatému žánrovému panoramatu.

Začněme od konce: sám Hulka-Laskowski nezanechal po sobě významnou stopu jako autor krásné literatury. Kromě regionálně pojaté, spíše populárně a publicisticky laděné knihy o Žyrardově Mój Żyrardów (1934), věnované „robotnikom żyrardowskim, towarzyszom walki $i$ porażek z wyrazem nieztomnej wiary w ostateczne zwyciestwo“, a nedokončeného románu o římském básníkovi Catullovi, napsal ještě román ze života evangelíků Porucznik Regier (1927). Dále sestavil rozsáhlou antologii Pięć wieków herezji (1939), reportáž ze života obyvatel na českém Těšínsku, z tzv. Záolží, ${ }^{6}$ Ślask za Olza (1938), a rozsáhlý text o Čechách, jehož rukopis shořel během varšavského povstání v roce 1944.

O něco bohatší je Hulkova překladatelská práce. Překládal z angličtiny, francouzštiny, němčiny, češtiny a ruštiny. Polští čtenáři se jeho prostřednictvím mohli seznámit s tituly, jako jsou (v překladu do polštiny) Przygody dobrego wojaka Szwejka Jaroslava Haška, Fabryka Absolutu a trilogie Hordubal, Meteor a Zwyczajne życie Karla Čapka, Babunia Boženy Němcové, Ameryka: Powieść o Lincolnie Emila Ludwiga, Rodzina Thibault Rogera Martina du Gard, Życie św. Franciszka z Asyżu Paula Sabatiera, Napoleon Dmitrije Merežkovského, Rokoko: Francja w XVIII-tym stuleciu Maxe von Boehna, Ludzie genialni Ernsta Kretschmera. (K překladům z češtiny se ještě vrátíme.) Překládal také aktuální evropskou publicistiku, včetně šesti svazků Sylvanuse Stalla o sexuální výchově a uvědomělém mateřství.

Publicistický a literárněkritický odkaz Hulky-Laskowského je neobyčejně rozsáhlý. Své články zveřejnil ve více než sedmdesáti periodikách, mimo jiné na stránkách novin a časopisů Wiadomości Literackie, Tygodnik Ilustrowany, Gazeta Polska, Polska Zbrojna, Czarno na Białym, Wolnomyśliciel, Bluszcz, Sygnały, Ilustrowana Republika, Nowy Dziennik, Ilustrowany Kurier Codzienny, a v řadě evangelických časopisů (v nich je mimochodem často citován do dnešních dnů). Přispíval také do zahraničních periodik Slavische Rundschau, Slovenský prehled a L'Europe Centrale. V poválečném období spolupracoval s katovickou Trybunou Robotniczou, Odrodzeniem, Warszawou a Głosem

5 HULKA-LASKOWSKI, Pawel: Księzyc nad Cieszynem. Katowice: Wydawnictwo „Literatura polska“, 1946, s. 114.

6 Oba termíny české Těšínsko a Záolží se přitom zcela nepřekrývají, pod druhým rozumíme bývalé politické okresy Těšín a Fryštát. (Jiné překlady pojmu Zaolzie, než jak je navrhuji a zdůvodňuji v odborném tisku, bez ohledu na to, zda jsou či nejsou nyní považovány za jakýsi úzus, nerespektují zásady české slovotvorby. Srov. mj. MARTINEK, Libor: Jak překládat pojem Zaolzie? Těšínsko, 2010, č. 3, s. 28-30.) 
Żyrardowa. Tato neobyčejná aktivita vyplývala z Hulkova přesvědčení, že posláním publicistiky je usměrňování aktivit vlády.

Hulka-Laskowski se osobně málokdy účastnil veřejných shromáždění, byt se svou manželkou Kazimierou (rozenou Uhlenfeld, dcerou žyrardovského knihvazače, s kterou se oženil během svých studií) v době, kdy byl v roce 1920 tiskovým referentem, se v Praze zúčastnil oslav 1. máje, jimiž byl upř́ímně okouzlen. Jinak byl samotářem, jenž byl svými současníky nazýván žyrardovským poustevníkem. Nebyli daleko od pravdy, ale objektivně byla jeho osamocenost a uzavřenost dána tím, že tento spisovatel a publicista trpěl agorafobií a také se mu výrazně zhoršil sluch. Svůj kontakt se společenským životem nahrazoval četbou širokého spektra novin a časopisů.

Na vytvoření jeho postoje $\mathrm{k}$ soudobé skutečnosti mělo vliv vědomí tradic reformace, intelektuálního a emocionálního dědictví po předcích, kteří bojovali za svobodu svědomí. Edward Madany se dokonce odvážil formulovat názor, že byl pokračovatelem postoje charakteristického pro lidi, kteří myšlenkově a duchovně vedli jednotu bratrskou ve vyhnanství. $\mathrm{Z}$ celé řady typických vlastností pro tyto vůdce je třeba uvést jednu - tu nejhlavnější: vášnivé, nekompromisní hledání pravdy. Pojetí pravdy nejenom jako ctnosti, měřítka všech hodnot, ale také zbraně v bitvě o štěstí lidstva. ${ }^{7}$ Téměř ve všech pracích Hulky-Laskowského se téma pravdy odvijí jako Ariadnina nit smyslu textu. Jako by se v nich odráželo husitské heslo „Pravda vítězi“. (Vzhledem k tomu, že v nietzcheovské tradici, rozvíjené zejména současnými dekonstruktivisty, je pravda chápána jako relativní, nebude od věci připomenout, že původní heslo husitů znělo „Pravda boží vítězi“.) Veden právě touto mocí pravdy, která se opírala o Hulkova hluboká filozofická a religiózní studia vývoje kultury a společnosti, vytvářel si svůj postoj ve vztahu k českému písemnictví, ke krásné literatuře a dalo by se říci: $\mathrm{k}$ českému národu a jeho kultuře vůbec.

Vzhledem $\mathrm{k}$ tomu, že se stával častou obětí útoků v tisku, nebyla jeho literární ani lidská cesta jednoduchá. Zejména během kampaně za zlepšení životních a pracovních podmínek v textilním závodě v Žyrardově (poté, kdy firmu převzalo francouzské konsorcium Marcela Boussaca), ale i ze strany nacionalistů a bojovných klerikálů, nebot byl přivržencem náboženské tolerance. Později, koncem třicátých let minulého století, se mohl obávat také pomsty místních Volksdeutschů za antifašistické články. ${ }^{8}$ Své filozoficko-religionistické práce vesměs publikoval pod literárními pseudonymy K. Haworka, J. Oścień, J. Adamczyk, T. Gruda, S. Pralacik atp. Spolupracoval s redakcemi časopisů Ewangelik, Głos Ewangelicki, Przegląd Ewangelicki, Szlak Reformacji a Nowe Drogi. Redigoval rovněž časopis Pielgrzym Polski a vedl Evangelicko-polskou tiskovou kancelár (Ewangelicko-Polskie Biuro Prasowe). Rozhodně vystupoval proti stereotypu Poláka-katolíka. Zastával názor, že pouze smíření náboženství by uvolnilo myšlenkový pohyb, který

7 Srov. MADANY, Edward: Pawet Hulka-Laskowski - Ttumacz i popularyzator literatury czeskiej w Polsce. In: Studia poświęcone stosunkom literackim polsko-czeskim i polsko-słowackim. Wrocław - Warszawa - Kraków: Zakład Narodowy imienia Ossolińskich - Wydawnictwo Polskiej Akademii Nauk, 1969, s. 139.

8 Již v roce 1933 ve svých článcích (mj. Niemcy bez maski, Koszulizacja Niemiec, Rasa nordycka) potírá fašismus a antisemitismus. Zesměšňuje samého Hitlera, když v okně půjčovny knih Zdrój (založené jeho manželkou v roce 1930 a dcerou Elżbietou, jíž se dostalo humanitního vzdělání na univerzitě ve francouzském Grenoblu - studia úspěšně ukončila v roce 1930), vystavuje dobrodružný román, který kdysi napsal sám Führer. Tím přivede k zuřivosti místní Němce, kteří stále hlasitěji manifestují své národně socialistické sympatie. 
by byl schopen vytvořit silný polský národ, jenž by se mohl vyrovnat vedoucím národům Evropy. Vyslovoval se rovněž na téma reformy manželského práva. Otevřeně také podporoval spisovatele Tadeusze Boye-Żeleńského (1874-1941) v kampaních vedených proti jeho Dziewicom konsystorskim (1929) a Piektu kobiet (1930). Tím si proti sobě popudil na dlouhou dobu katolickou církev. Kromě toho byl po válce nespravedlivě obviňován z levičáctví. Mohli bychom se zamýšlet nad tím, jak by vypadal jeho životaběh, kdyby nezemřel v roce 1946, zdali by nepřipomínal osud Gustawa Morcinka (1891-1963), jenž byl před válkou podobně jako Hulka zastánce sanace (na Horním Slezsku ztělesněné a reprezentované vojvodou Michałem Grażyńským), po převzetí vlády komunisty byl autor Ondraszka (1953) poslancem sejmu PLR (1952-1957) za oblast Katovice.

Hulka sám přispěl, byt nechtě, k zamotání osudů básníka, frýdeckého rodáka Óndry Łysohorského (vl.jm. Ervín Goj; 1905-1989), který v důsledku sílícího fašistického hnutí na Slovensku, kde v té době žil, zejména po vzniku klerofašistického Slovenského štátu, hledal práci v Horním Slezsku. Ze Wspomnień (2001) katovického spisovatele a publicisty Wilhelma Szewczyka ${ }^{9}$ se dovídáme o Łysohorského dvojím pobytu v Katovicích, o tom, jak hledal práci ve školství, ale nemohl ji v roce 1939 najít, jelikož mu Paweł Hulka-Laskowski ve svém Ślasku za Olza přilepil nálepku komunisty - a vojvoda Michał Grażyński členy nebo jen sympatizanty této strany neměl v lásce. ${ }^{10}$ Kromě toho se sám nepovažoval za Poláka, prý „nazywat siebie jedynie ślaskim Polakiem“. ${ }^{11}$ Nakonec jeho polští přátelé - Szewczyk tehdy pracoval v literární redakci katovického rozhlasu - našli východisko. Hlavní redakce Polského rozhlasu ve Varšavě plánovala pro oddělení politických zpráv vysílání ve slovenštině. Do Varšavy však Łysohorsky už nedojel, jeho vlak se zastavil někde nad Vislou na rozbombardované trati. Odtud šli všichni pěšky směrem na východ, k řece Bug, kde se básník dostal do sovětského zajetí. ${ }^{12}$

Znalost češtiny si Hulka neodnesl z domova. Poprvé si uvědomil, že je potomkem českých exulantů, když jako chlapec pracoval v žyrardovské textilní továrně, kam přišla za prací skupina dělníků ze Zelova, rovněž z rodin někdejších vystěhovalců z Čech. Hulkovo přátelství s mladým dělníkem Procházkou, které vzpomíná v knize Mój Żyrardów, ho přivedlo k pokusu o ovládnutí českého jazyka stejným způsobem, jakým se učil francouzštinu, řečtinu, latinu. Začal číst české knihy, i když tak, jak mu zrovna přišly do rukou, dokonce začal číst Herbenův časopis Čas, se kterým spolupracoval také Tomáš Masaryk a do něhož mj. přispěl svými básněmi Petr Bezruč (v roce 1903 vydal Herben

9 SZEWCZYK, Wilhelm: Wspomienia. Ed. Grażyna Szewczyk. Red. Wojciech Janota. Katowice: Wydawnictwo Naukowe „Śląsk“, 2001, s. 149.

10 Nakonec dostal př́ślib výuky němčiny na gymnáziu v Těšíně, ale až po prázdninách; mezitím se Łysohorsky vrátil do Bratislavy, kde měl mladou ženu. Po jeho odjezdu uveřejnil Zdzisław Hierowski ve Fantaně článek Straciliśmy przyjaciela, kde poněkud neštastně připomněl nesplněné sliby vojvodského úřadu pomoci Łysohorskému. Článek převzal časopis Slovák v Bratislavě a redakce si ho upravila tak, aby z něj vyplývalo, že Łysohorsky je placeným špionem polské vlády, takže mu ted' hrozilo obvinění z vlastizrady tehdy ještě mladého Slovenského štátu. A tak se Łysohorsky objevil v Katovicích podruhé. Na to, aby začal vyučovat na gymnáziu, bylo už pozdě. (Tamtéž, s. 149.)

11 Tamtéž, s. 152.

12 Srov. MARTINEK, Libor: $K$ recepci osobnosti a dila Óndry Eysohorského na Těšinsku a Horním Slezsku. In: Práce a studie Muzea Beskyd - společenské vědy, 2007, č. 18, s. 79-91. 
1. číslo Besed Času s podtitulem Slezské č̌slo). Z té doby je dochována korespondence mezi Hulkou-Laskowským a profesorem Karlovy univerzity, pozdějším prvním prezidentem Československa. Ve svém dopise z roku 1906 se obrátil na Masaryka, jako na morální autoritu, s prosbou o pomoc $\mathrm{v}$ řešení složitých problémů spojených s národnostními otázkami. Jednou z nich byla kardinální otázka: „dlaczego cztowieka tak nieludzko boli ucis$k^{\text {“13. }}$ V dopise z 16. 12. 1906 prof. Masaryk mu mimo jiné laskavě odpověděl: „Vážený pane, [...]. Prosím prěčěte si: Masaryk, Ideale der Humanität [...], Lagarde, Deutsche Schriften vám poskytnou hodně materiálů $k$ přemýšleni; konec koncư je národnost uložena na mravním přsvèdčeni, a proto ji hájime proti potlačovatelům [...]. Jde však nejen o obranu - je třeba směrovat $k$ vyššim ideáliom Nejlepšimi vlastenci často bývali proroci, kteři vedli své národy $k$ vy̌šśm mravním ideálům. [...] Väš T. G. Masaryk. "14 Později, v knize vzpomínek Měsíc nad Těšínem, se k Masarykově myšlence vrací znovu, ale o tom se ještě zmíníme.

Prvním Hulkovým překladem z češtiny byl satirický román Jestř́a kontra Hrdlička Svatopluka Čecha. Výběr titulu byl náhodný a překlad mu zabral prý deset dní, jak vzpomíná v Mém Žyrardovè. K jeho překvapení translace vyšla v Knihovně vybraných děl (Biblioteka Dzieł Wyborowych) jako prémie varšavské Gazety Polskiej. ${ }^{15}$ Estetická hodnota tohoto překladu není velká. Lze pozorovat značnou závislost stylu na českém originálu, na specifičnosti české větné stavby. „Polszczyzna jest nader uboga i zgrzebna, zwtaszcza w partiach opisowych. Ttumacz nie umiat sobie poradzić z powiazaniem zdan podrzednie ztożonych. Przy tych wszystkich niedociagnięciach $i$ naiwnościach debiutanckiej pracy traslatorskiej zaskakuje fakt, że nie ma w niej btędów rzeczowych, wyptywajacych z nieznajomości jezyka originatu. "16 Hulka v celém textu „překládá“ (spíše adaptuje) př́ijmení Hrdlička jako „Hordliczka“, přitom logičtější překlad nejen lexikálně, ale i z důvodu charakteru postav (jde o nomina omina) by byl Synogarlica. Postupoval tak prý záměrně kvůli usnadnění výslovnosti. ${ }^{17}$ To by se však týkalo obtížnější výslovnosti českého př́ijmení v ústech Poláka (neuvyklého ve své rodné mluvě sestavení po sobě jdoucích souhlásek „hrdl“, kdy „r“ v polštině není na rozdíl od češtiny sylabotvorné - srov. "gordlo“ - proto bylo třeba vložit samohlásku „o“: „hordl“; kromě toho je polská výslovnost souhlásky „h“ jako „ch“ [Chordliczka]), nikoli polského př́ijmení jednoho z titulních hrdinů, jež by bylo identické s polským názvem tohoto opeřence z čeledi holubovitých. Tímto způsobem translátor zjednodušil satirickou vrstvu díla a smazal autorův umělecký záměr vytvoření kontrastu mezi oběma hrdiny novely. Sám spisovatel po letech zhodnotil tento debutantský pokus vstoupit na území literatury jako akt „dobrej woli, serdecznego sentymentu i lichutkiego jezyka“ ${ }^{18}$ Další Hulkovy překladatelské práce jsou již po všech stránkách zdařilejší, umělecky působivější.

Motivován vydáním Jestrába kontra Hrdličky přeložil v roce 1902 během jednoho měsíce humoristický román Ignáta Herrmanna Otec Kondelik a ženich Vejuara, prostoupený

13 HULKA-LASKOWSKI, Paweł: Ślask za Olza. Katowice: Wydawnictwa Instytutu Śląskiego, 1938, s. 444.

14 Tamtéž, s. 444.

15 ČECH, Svatopluk: Jastrzab kontra Hordliczka. Přel. Paweł Hulka-Laskowski, Warszawa: Biblioteka Dzieł Wyborowych, 1901.

16 MADANY, Edward: Pawet Hulka-Laskowski... Op. cit., s. 140.

17 HULKA-LASKOWSKI, Paweł: Mój Żyrardów. Warszawa: Wydawnictwo J. Przeworskiego, 1934, s. 143.

18 Tamtéž, s. 136. 
lidovou žoviálností. Výběr titulu byl opět náhodný, knihu mu totiž podstrčil topič v kotelně žyrardovské fabriky - Čech původem. Vychován v chudých podmínkách dělnického prostředí, našel v ní naivní odraz ideálního světa laskavých vztahů mezi lidmi. Využil také skutečnosti, že se Gazeta Polska snažila v roce 1902 zvýšit počet svých předplatitelů, proto zvětšila množství prémiových knižních titulů v edici Knihovna vybraných děl a knihu v tom roce vydala. ${ }^{19}$ Ve srovnání s prvním překladem můžeme zaznamenat určitý kvalitativní posun. Překladatel nepřekládá doslovně či otrocky, volněji pracuje s jazykem, přirozeněji ukládá složitá souvětí, i když jeho slovní zásoba je stále ještě chudá. Občas se vyskytnou kalky české větné skladby nebo ve flexi, nap̌r.: „kwiecie tropicznego lasu“, jak na to upozorňuje Edward Madany. ${ }^{20}$

Po letech se ještě vrátil k próze Ignáta Herrmanna, když z ní vybral román napsaný dříve než Otec Kondelik..., obsahující společensko-kritické akcenty v načrtnutém obraze ubohé existence obchodníka zbaveného obchodu - U snědeného krámu. V roce 1923 se mu již nepodařilo získat nakladatele: „[... [ ręopis dwutomowej powieści przepadt $i$ trzeba byto pogodzić sie z losem “. ${ }^{21}$ Herrmann zaujal Hulku-Laskowského popisem života chudých lidí, upřímností v zobrazení tématu tak blízkého kronikáři - bídy žyrardovských dělníků.

Silný vliv na Hulkovo uvažování o literatuře, kultuře a politice měl dvousvazkový zápisník Josefa Svatopluka Machara (1864-1942) Konfese literáta (1900-1901), v němž je obsažena pravdivá, obnažená a nepřikrášlená podoba emocionálních stavů a zážitků dospívajícího mladého člověka.

Pro Hulku-Laskowského měl první kontakt s Macharovým dílem velký význam. Pod jeho vlivem začal pochybovat o hodnotě a pravdivosti ctností chápaných nábožensky. Od tohoto postoje vedla přímá cesta $\mathrm{k}$ negování všech mýtů a morálních příkazů hlásaných katolickou církví a k přátelství s Andrzejem Niemojewským (1864-1921), jenž jeho tvorbu dále výrazně ovlivnil. ${ }^{22},[. .$.$] jakoś niewyraźnie wyczuwatem, że w prawdzie i$ prawdziwości jest mocne, zuchwate piękno. "23 Od té doby jeho obcování s Macharem, jenž ho zajímal hlavně „jako zjadliwy liryk, autor niezapomnianych Wyznań i bliski przyjaciel Masaryka“,24 bude trvat dlouhá léta. V roce 1923 přeložil jeho Řim, jedno z děl rozvíjejících macharovskou koncepci lidské civilizace od nejdávnějších dob do současnosti. Nicméně pro svůj překlad nenašel vydavatele. Kromě toho se Macharova stopa hodnocení české literatury projevuje v Hulkových literárněkritických pracích, které tomuto tématu věnoval.

19 HERRMANN, Ignát: Ojciec Kondelik i narzeczony Wejwara. Přel. Paweł Hulka-Laskowski. Warszawa: Biblioteka Dzieł Wyborowych, 1902.

20 MADANY, Edward: Pawet Hulka-Laskowski... Op. cit., s. 141.

21 HULKA-LASKOWSKI, Paweł: Mój Żyrardów. Op. cit., s. 141.

22 Zde je nutno podotknout, že Niemojewského básnická sbírka Polonia irredenta (1895) byla inspirována autorovým pobytem ve Slezsku a má výrazný sociálně kritický tón (jistou analogií v české literatuře jsou Slezské pisně Petra Bezruče). Ve svých článcích a studiích se značně kriticky zabýval náboženskými otázkami. (Srov. KARDYNI-PELIKÁNOVÁ, Krystyna: Andrzej Niemojewski. In: Slovník polských spisovatelů. Praha: Libri, s. 352.)

23 Tamtéž, s. 132.

24 Tamtéž, s. 160. 
Bližší a systematičtější zájem Hulky-Laskowského o českou literaturu se datuje od roku 1920, kdy působil tři měsíce v Praze jako tiskový referent polského ministerstva zahraničních věcí. V té době se setkal s českými spisovateli, četl český tisk, sledoval nálady společnosti prožívající radost z osvobození. Vzpomínky z pobytu v Československu tvoří v Mém Žyrardově samostatnou část, představují specifickou impresivní reportáž naplněnou obdivem k této zemi a zároveň občanskou starostí o osudy své vlasti. Hulka neustále konfrontuje poválečnou československou skutečnost se situací v Polsku. Jako tiskový referent byl seznámen se vznikajícími neporozuměními mezi oběma státy, které se ve třicátých letech minulého století ještě značně prohloubily a vedly k problémům na Těšínsku. Snad proto bezprostředně po návratu do vlasti informuje Hulka-Laskowski polské společenství o české problematice a zejména o české literatuře. Dá se říci, že se věnoval podobné činnosti jako neúnavný polonofil Edvard Jelínek v Čechách ke konci 19. století s tím rozdílem, že Hulkova aktivita byla selektivnější, úžeji zaměřená, závislá na osobních názorech a preferencích. Hulka informuje a hodnotí zároveň. Píše-li o české literatuře a vybírá-li z ní určité tituly k překladu, používá ustálený kritický aparát. ${ }^{25}$

V roce 1923 zveřejňuje Hulka-Laskowski v měsíčníku Przegląd Warszawski, redigovaném Wacławem Borowym, obsáhlou studii o vývoji české literatury od počátků českého písemnictví až po práh dvacátého století. ${ }^{26}$ Věrný svým profesionálním zájmům v oblasti kulturních dějin sleduje paralelnost nebo dokonce protikladnost dvou kulturních vrstev v životě Čechů v období středověku - vrstvy lidové, obsahem světské, nasycené zdravým humorem i autentickým optimismem, a vrstvy dvorské kultury, značně konvenční a ovládané německým živlem. Šlo o značné zjednodušení, avšak zřejmě nezbytné v tak stručném pojetí celku české středověké kultury. Veden osobním sentimentem vưči pozitivním stránkám české reformace vyzvedl zásluhy jednoty bratrské na formování nauky a etiky společenství jinověrců. Naopak literaturu národního obrození charakterizoval jen krátce, jelikož ani v tvorbě básníků, kteř́i byli zčásti i etnografy (Pavel Josef Šafař́ík, Ladislav Čelakovský a jiní), ani v literatuře podřízené cílům rekonstrukce národního jazyka (např. Puchmajerova škola) nenašel vlastnosti autentického umění. V tomto ohledu se blí̌zil pařížským přednáškám Adama Mickiewicze o slovanských literaturách, aniž si uvědomil, že v Polsku na rozdíl od Čech vysoká kultura (styl, jazyk) nikdy zcela nezanikla a významní polští romantikové měli svá umělecky náročná díla stále komu adresovat. Kritériem umělecké pravdivosti mu byla nezávislost umění na konvencích a jakékoli utilitární tendenci. „Autentyczna sztuka, jego zdaniem, polega na umiejętnym i idacym w gtab zagadnień oddzielaniu prawdy od iluzji, wydobywaniu przeciwieństw między różnymi obliczami tego samego zjawiska czy przedmiotu analizy. "27 Teprve Karla Hynka Máchu označil Hulka za skutečného básníka obdařeného romantickou osudovou silou. Hned vedle něho umístil tvorbu Boženy Němcové, nebot' v ní nalezl protiklad „tragedię przeciwienstw między wielkimi pragieniami petni życia a nędzna rzeczywistościa bezustannej poniewierki“ ${ }^{28}$ Podob-

25 Srov. MADANY, Edward: Pawet Hulka-Laskowski... Op. cit., s. 142.

26 HULKA-LASKOWSKI, Paweł: Rozwój literatury czeskiej. Przegląd Warszawski, 1923, sv. 2, č. 21, s. $296-318$.

27 MADANY, Edward: Pawet Hulka-Laskowski... Op. cit., s. 143.

28 HULKA-LASKOWSKI, Paweł: Rozwój literatury czeskiej. Op. cit., s. 306. 
ně vysoce ocenil satirickou tvorbu Karla Havlíčka-Borovského, tepajícího despotismus a klerikalismus, která mu připomínala svým deziluzivním a demaskátorským zaměřením Macharův umělecký postoj. Jeho prizmatem také nahlížel výsledky české literatury šedesátých a sedmdesátých let 19 . století. Dobře je to vidět $\mathrm{v}$ jeho negativním postoji k sentimentální a konvenční lyrice Vítězslava Hálka, k němuž stavěl do protikladu tvorbu Jana Nerudy. Také je to patrné v odtažitém představení tvorby Jaroslava Vrchlického (jinak ovšem v Polsku dobře přijatého díky propagátorskému a překladatelskému úsilí Marie Konopnické), jemuž Hulka vytýkal eklektičnost, přehnaně hermetickou estetiku a inspiraci díly světové literatury. Ve vztahu k dílu Aloise Jiráska se Hulka odvážil podle Edwarda Madanyho k samostatnému a odvážnému kritickému postoji: „Dziela Jiráska sa raczej kronikami niż kompozycjami powieściowymi, czyta się je ogromnie tatwo, bez jakiegokolwiek wysitku i dlatego lubi je lud czeski. Mniej zrozumiate jest, dla czego Akademia Czeska i instytucje pokrewne nagradzaja wszystkie niemal dzieta tego pisarza [...], boć sumienny krytyk o pewnych wymaganiach wzgledem samego siebie musi sobie powiedzieć, że dzieła Jiráska nie sa bynajmiej dzietami artystycznymi. “29

Proč se Hulka-Laskowski tak kriticky vyjádřil o Jiráskově díle, na to už Madany neodpovídá. Kritické hodnocení tvorby autora Psohlavců nemuselo být vyvoláno jenom národním literárním kontextem, v němž se ke slovu dostávají modernisté, ale nejspíše komparací a z ní vyplývajícího uvědomění si kvalit soudobé polské literární, v tomto případě zejména prozaické tvorby Władysława Stanisława Reymonta nebo Stefana Żeromského - a před nimi samozřejmě nepřehlédnutelného Henryka Sienkiewicze (modernistickou poezii reprezentovanou jmény jako např. Stanisław Przybyszewski, Jan Kasprowicz, Kazimierz Przerwa Tetmajer či Lucjan Rydel pro domo sua necháváme stranou).

Hulka-Laskowski se ve své studii také obdivně vyjádřil o Macharovi za to, že téměř jako "fanatyk prawdy i prawdziwości wtargnat do literatury, drwiac z bożyszcz, których potęg polegata jedynie na konwencjonalizmie ich czcicieli“30. Za podobně nekompromisní útok, soustředěný ovšem jiným směrem, chválí poezii Petra Bezruče (vl. jm. Vladimír Vašek; 1867-1958) obdařenou vášnivostí ve vztahu k sociálnímu útisku slezského proletariátu.

Článek Hulky-Laskowského ve Varšavském přehledu je důležitým počinem v jeho kritické a překladatelské aktivitě. $V$ něm upřesnil své záliby, svůj vlastní vztah k české literatuře, kterou v té době znal již poměrně dobře. Můžeme v něm spatřovat i předpověd' pozdějších Hulkových kontaktů s díly vybraných autorů, návratů k určité četbě a volbě přisvojení některých děl polským čtenářům prostř̌ednictvím překladu. K těmto Hulkou vyvoleným patřili bezpochyby Božena Němcová, Karel Havlíček-Borovský a samozřejmě Josef Svatopluk Machar.

Nákladem novin Robotnik Śląski vydal Hulka-Laskowski ve Fryštátu pod pseudonymem překlad satirické poemy Havlíčka-Borovského Křst svatého Vladimíra. ${ }^{31} \mathrm{~V}$ úvodu svým typickým způsobem podtrhl hodnotu tohoto díla v probuzení „,umystów zahukanych“ a ukázání cesty, jak dospět k pravdě nezfalšované žádnými politickými a náboženskými

29 Tamtéž, s. 315.

30 Tamtéž, s. 315.

31 HAVLÍČEK-BOROVSKÝ, Karel: Chrzest św. Wtadymira. Legenda z dziejów Rosji. Przeł. z czeskiego S. Prałacik. Frysztat, 1923. 
iluzemi. Překlad „wiernie zachowat rytmike $i$ strofike originatu. Miejscami jednak jest nieadekwatny. Zmienia bowiem specyfike stownictwa poematu. Hulka czasem nadmiernie konwencjonalizuje styl $i$ stownictwo w swoim przektadzie, niekiedy znów ubarwia go dialektyzmami“ “. ${ }^{32}$ Jaromír Bělič, jenž určil autorství překladu Křtu svatého Vladimíra na základě informací obdržených od těšínského historika Ludwika Brożka, porovnal kvalitu polského překladu s jinými translacemi tohoto díla a dospěl k závěru, že „kvality překladu svědči o značné spisovatelské, básnické dovednosti překladatelově a o velmi dobré znalosti jazyka originálu" "33. ${ }^{34}$

$\mathrm{O}$ čtyři roky později vyšel překlad Babičky Boženy Němcové, ${ }^{35}$ který Hulka-Laskowski provedl s „dużym pietyzmem dla dzieta czeskiej pisarki i zrozumieniem jej prostej, ale artystycznie wykrystalizowanej naracji“. ${ }^{36}$ Toto klasické dílo české literatury zaujalo translátorovu pozornost nejen kvůli svému obsahu, ale také pro umělecké zobrazení typu českého člověka z lidu, který projevuje moudrý postoj vưči skutečnosti.

V roce 1927 navázal spolupráci s jiným významným polským časopisem - Wiadomości Literackie, kam zaslal svou polemiku s názory prof. Tadeusze Zielińského obsaženými v jeho knize Helenizm i judaizm (1927). Od té doby až do roku 1939 často publikoval na stránkách „Literárních zpráv“ příspěvky s religionistickou, sociologickou a literární tematikou. Psal také recenze na odborné a literární publikace (podle jeho názoru nejzajímavější), které vycházely v Polsku nebo v zahraničí. Spolupráce s „Literárními zprávami“ ho velmi naplňovala, nebot' v nich mohl polemizovat se všemi projevy netolerance v oblasti vědy, literatury a lidského myšlení. Vyvolal také velkou diskusi svými úvahami na téma proletářské poezie, ${ }^{37}$ což bylo téma probírané rovněž v české literární kritice, avšak kulturní kontext byl v obou zemích poněkud odlišný. Hulka vytýkal polské kritice a inteligenci obecně značné omezení v chápání revoluce, značnou politickou naivitu. Na polemice lze ocenit solidaritu autora s protesty a požadavky dělníků: „[...] poezja proletariatu jest wiara wyrastajaca z uzasadnionego wstrętu do świata chamstwa i obtudy, chowajacego się za najszczytniejszymi hastami religii chrześciańskiej. " ${ }^{38}$ Článek byl inspirován četbou poemy Trzy salwy Stanisława Standeho, Władysława Broniewského a Witolda Wandurského, přičemž se v něm jeho autor zmínil o významném českém básníkovi proudu proletářské poezie Jiřím Wolkerovi. Existují svědectví, že Hulka zamýšlel přeložit i jeho poezii do polštiny, ${ }^{39}$

32 MADANY, Edward: Pawet Hulka-Laskowski... Op. cit., s. 144.

33 BĚLIČ, Jaromír: Neznámý překlad Křtu svatého Vladimíra do polštiny. In: Franku Wollmanovi k sedmdesátinám. Praha: SPN, 1958, s. 233-242.

34 Tento celý odstavec (a nejen ten) byl vypuštěn zásahem redakce do polského překladu našeho př́íspěvku, jenž vyšel ve značně zkrácené podobě v časopise Zwrot pod názvem Pawet Hulka-Laskowski - budowniczy pomostów między narodami (Zwrot, 2013, č. 9, s. 44-46), na což v zápětí (v dalším čísle Zwrotu) reagovala brněnská polonistka prof. Krystyna Kardyni-Pelikánová článkem, který měl doplnit tuto chybějící, přitom značně podstatnou část naší statě.

35 NĚMCOVÁ, Božena: Babunia. Přel. P. Hulka-Laskowski. Łódź - Katowice: Nakładem Księgarni Ludwika Fiszera, 1927; další vydání vyšlo v Bibliotece Narodowej, 1951.

36 MADANY, Edward: Pawet Hulka-Laskowski... Op. cit., s. 145.

37 HULKA-LASKOWSKI, Paweł: Poezja szlachetnego nieporozumienia. Wiadomości Literackie, 1928, č. 1, s. 1; č. 7 , s. 1 .

38 Tamtéž, č. 1, s. 1.

39 BROŻEK, Ludwik: Pawet Hulka-Laskowski. Odra, 1946, č. 40, s. 6. 
ale od tohoto záměru odstoupil poté, kdy se objevil výbor Wolkerových básní v překladu manželů Kazimiery a Stanisława Alberti. ${ }^{40}$ Nešlo přitom o jediný polský předválečný překlad Wolkera; s výborem z jeho veršů přišel i polský básník z českého Těšínska Adolf Fierla (1908-1967), ${ }^{41}$ který o něm napsal i popularizující stat Jerzy Wolker i jego dzieto (1933).

Wiadomości Literackie se staly tribunou popularizace české literatury. Hulka o ní nejen informoval, ale také apeloval na vydavatele. Využíval ji jako prostředek k prosazení svých překladatelských plánů. V roce 1927 se stručně zmínil o románu Karla Matěje Čapka-Choda (1860-1927) Antonín Vondrejc, příběhové básnika (1. vyd. 1917-1918), ${ }^{42}$ jenž zobrazoval české umělecké prostředí, a přestože byla Hulkovi umělecká východiska naturalismu cizí, nebot je označoval za vulgární a plytké, pochválil toto dílo za hlubokou analýzu fatalismu a pesimismu, které jsou ponořeny na dně lidské duše.

Zakrátko poté informoval na stránkách „Literárních zpráv“ o kulturních časopisech v Československu. Zejména se soustředil na polonika, která se objevovala v Rozpravách Aventina a v Literárním světě. ${ }^{43}$ Podal také portrét českého symbolistického básníka Antonína Sovy (1864-1928) a v jeho tvorbě zdo̊raznil vlastenecký prvek. ${ }^{44}$ Připomněl polskému čtenáři známou Sovovu báseň (díky překladu M. Szukiewicze ${ }^{45}$ ) - odpověd' Theodoru Mommsenovi z roku 1897, kterou Sova napsal po šovinistickém, protičeském vystoupení německého historika v Neue Freie Presse. Při obecném přehledu knižních novinek vydaných v Československu opět vyzdvihl práce J. S. Machara a jenom okrajově připomněl Hovory s T. G. Masarykem (vycházely postupně, po částech, v letech 1928, 1931 a 1935) Karla Čapka. ${ }^{46}$ V Literárních zprávách také recenzoval knihu Jana Magiery Literatura czeska i stowacka: Zarys piśmiennictwa (1929), která v Polsku poprvé podala celkový přehled vývoje české a slovenské literatury. ${ }^{47}$ Přestože měl Hulka vlastní a odlišnou koncepci kritického hodnocení vývoje české literatury, ocenil oprávněnost Magierovy selekce materiálu pro potřeby zahraničního čtenáře. Při posouzení kompozice a periodizace látky v Magierově knize byla Hulkovým srovnávacím kritériem velká antologie Paula (též Pavla) Eisnera Die Tschechen: Eine Anthologie aus fünfJahrhunderten (München, 1928). V roce 1933 vychází obsáhlejší Hulkova studie o mladé české próze, ${ }^{48}$ která pak v přepracované a rozširrenené verzi vyšla ještě na stránkách časopisu Pion. ${ }^{49}$ Studie zabírá časové rozmezí let 1914-1935.

Hulka zřejmě sledoval poměrně systematicky vývoj české literatury po první světové válce, místy však došel k poměrně osobitým a diskutabilním závěrům. „Stwierdzit bowiem,

40 WOLKER, Jerzy: Gość w domu. Přel. K. i S. Alberti. Warszawa: Nakładwem Księgarni F. Hoesicka, 1927.

41 WOLKER, Jerzy: Wiersze wybrane. Praha: V. Petr, 1934.

42 HULKA-LASKOWSKI, Paweł: Ten drugi Čapek, czyli hiperkompozycja. Karel Matěj Čapek-Chod. Wiadomości Literackie, 1927, č. 43, s. 1 .

43 HULKA-LASKOWSKI, Paweł: Czasopiśmiennictwo czeskie. Wiadomości Literackie, 1928, č. 8, s. 2.

44 phl: Antonín Sova. Wiadomości Literackie, 1928, č. 40, s. 2.

45 SOVA, Antonín: Teodorowi Mommsenowi. Přel. M. Szukiewicz. Życie, 1897, č. 12, s. 2.

46 HULKA-LASKOWSKI, Paweł: Czeskie nowości w „Aventinum“. Wiadomości Literackie, 1929, č. 24 , s. 4.

47 phl: Literatura czeska i stowacka J. Magiery. Wiadomości Literackie, 1929, č. 9, s. 4.

48 HULKA-LASKOWSKI, Paweł: Mtoda proza czeska. Wiadomości Literackie, 1933, č. 37, s. 5.

49 HULKA-LASKOWSKI, Paweł: Wspótczesna literatura czeska. Pion, 1935, č. 41, s. 4. 
że linia rozwojowa wiedzie od ludowego optymizmu $i$ krzepy tej literatury za czasów niewoli narodowej do »anarchii moralnej « $i$ katastrofizmu. "50 Při analýze tvorby Karla Čapka, který podle jeho názoru "pirandellizuje najdrobniejsze i najpowszedniejsze wydarzenia życia“ ${ }^{51}$ dospívá k mínění, že „wielki demokrata Čapek jest Janem Chrzcicielem faszyzmu, mimowolnym, bezwiednym, fatalnym “.52 Edward Madany se o významu tohoto Hulkova nepříliš štastně formulovaného názoru domnívá, že: „Laskowski miat na myśli proroctwa Čapka o nadejściu faszyzmu. "53 Může tedy překvapit citlivost kritika, který takto psal o autorovi Války s mloky tři roky před vydáním knihy varující před nebezpečím fašismu (dílo bylo poprvé publikováno v letech 1935-1936 na pokračování v Lidových novinách, kniha vyšla v roce 1936). Avšak neměl Hulka na mysli přece jen cosi jiného, co by bylo více v kontextu s Luigim Pirandellim a jeho společenskými postoji, než s jeho literární estetikou a románovou stylistikou? ${ }^{54}$ Nepřipomněla Hulkovi čapkovská pirandellizace všedního života italského autora, hlásícího se k fašismu, přičemž této souvislosti si demokrat Čapek nemusel být vůbec vědom?

Hulka na stránkách Literárních zpráv uveřejnil svůj rozhovor s profesorem Karlovy univerzity v Praze Marianem Szyjkowským, v němž nacházíme upřesnění programu polsko-československé spolupráce, o kterou ostatně oba usilovali. ${ }^{55}$ Vystoupil s ním v době, kdy již beztak slabé československo-polské kulturní a politické kontakty na oficiální úrovni prakticky přestaly existovat. Tato skutečnost se bolestně dotkla mnoha Čechů i Poláků. Například u př́ležitosti deseti let od založení Československo-polského klubu byla v Brně vydána programová brožura Jdeme dál (1935), vyzývající k další činnosti v oblasti dobrých sousedských vztahů mezi dvěma národy a jejich kulturami. Český básník Antonín Klášterský se v novém otištění veršů Z českých žalmů (1911) ve Zvonu (1934), který také redigoval (1931-1938), odvolával na světlou minulost působení polské romantické poezie při probouzení národního sebevědomí Čechů. Josef Svítil-Kárník v předmluvě k překladu sbírky poezie Emila Zegadłowicze Budějovické louky (v orig. Budziejowickie taki, 1932), vydané česky roku 1934, citoval autorův dopis vyzývající k sjednocení obou národů tváří v tvář společnému nebezpečí. Hulka nejenže projevoval dobrou vůli a nadšení, ale viděl konkrétní formy spolupráce: „Gdzież się podziaty tamte pobratymstwa, zgody, jedności [...]. Dlaczego zasada etnograficzna została przecięta w Cieszyńskiem mieczem jakiejś

50 MADANY, Edward: Pawet Hulka-Laskowski... Op. cit., s. 146.

51 HULKA-LASKOWSKI, Paweł: Wspótczesna literatura czeska Op. cit., s. 4.

52 Tamtéž.

53 MADANY, Edward: Pawet Hulka-Laskowski... Op. cit., s. 147.

54 Luigi Pirandello (1867-1936) vstoupil roku 1924 do fašistické strany. Jeho skutečný vztah k režimu Mussoliniho je často diskutován v odborných kruzích. Těžko říci, zda Pirandellův př́íklon k fašismu byl jen vykalkulovaný záměr jak získat publicitu a přístup k dotacím, nebo zda skutečně platila jeho vlastní slova „jsem fašista, protože jsem Ital“. Na jedné straně Pirandellova poetika nikdy nebyla poplatná nabubřelému patosu Mussoliniho éry, na druhé straně je pravdou, že Mussoliniho podpora pomohla Pirandellovi získat mezinárodní slávu (jeho hry se hrály nejen v celé Evropě, ale také v USA a v Jižní Americe) a díky ní se také stal roku 1925 ředitelem římského divadla Teatro d'Arte (http://cs.wikipedia.org/wiki/Luigi_Pirandello; 30. 7. 2013).

55 HUlKA-LASKOWSKI, Paweł: Polacy $i$ Czesi. Rozmowa z prof. Marianem Szyjkowskim. Wiadomości Literackie, 1935, č. 42, s. 2. 
racji, która oddziela już nie tylko dwa państwa, ale izoluje dwa spoteczeństwa? Czy tegoż nie można $i$ nie należy naprawic?" ${ }^{56}$ Uvědomoval si, že nelze znovuoživovat zastaralá hesla o slovanské jednotě a bratrské pomoci. Hledal tedy moderní zpo̊soby stavění mostů spolupráce, které by odpovídaly historickým a kulturně-politickým podmínkám. Chtěl vytvořit instituce, které by mohly plnit funkci prostředníka ve všech sporech mezi státy. Jednou z nich měl být pedagogický institut, který by měl pobočku v Praze a Varšavě. Mládež, která by na nich studovala na výměnných pobytech, by poznala specifiku obou zemí a v budoucnosti by mohla objektivně řešit všechny spory a předcházet vzniku vzájemných negativních vášní mezi národy. Kromě toho požadoval širokou akci vzájemné informovanosti o minulosti a současnosti obou národů, o jejich národním charakteru a kultuře. Její realizaci spatřoval v systematické výměně spisovatelů, v pořádání výjezdů s autorskými čteními, ve vydávání početných tiskových zpráv. Byl to samozřejmě maximalistický program a Hulka si nakonec musel vystačit s minimální podobou, kterou každodenně realizoval spisovatelskou prací.

Již v roce 1927 se Hulka rozhodl, že přeloží slavný humoristický román Jaroslava Haška Osudy dobrého vojáka Švejka za světové války, který propagovali i německy píšící publicisté Max Brod a Hans Reimann. Navázal korespondenci s českým vydavatelem, ale nemohl najít polského nakladatele pro polský překlad. V Mém Žyrardově na tuto situaci vzpomíná takto: „Czytatem wtedy, nie wiem po raz który, Dobrego wojaka Szwejka [...]. Nie mogtem żadnego z wydawców przekonać, że to jest dobre i że to pójdzie. [...] Wydawca czeski zastrzegat się, że wszystkie nieparlamentarne stowa musza być przettumaczone dostownie bez żadnej eufemizacji $i$ wykropkowań. " ${ }^{57}$ Hulka tedy nejprve publikoval článek na téma této výjimečné knihy, v níž český satirik vytvořil nesmrtelný obraz českého vtipálka, mudrce a blázna. ${ }^{58}$ Shrnul v něm př́ihody Josefa Švejka za první světové války. K tomu přidal názory německých spisovatelů (soustředěných kolem Literarische Welt) na Haškův román. Ve svém příspěvku sice neprováděl žádnou analýzu díla, ale varoval před tím, že by román mohl být falešně chápán jako antologie kasárenských trivialit. „Jest to satyra pierwszorzędna, bezpośrednia i mocna, ale jak w Rabelais'm pewien typ czytelnika dostrzega przede wszystkim liczne przyktady jurności, przeoczajac to, co sie za nimi kryje, tak i bezpośredniość Haška myli na pierwsze spojrzenie. "59 Po této prezentaci „Švejka“" se v Polsku našel významný vydavatel. Postupně od roku 1929 nákladem nakladatelství Rój začaly vycházet všechny čtyři díly románu. ${ }^{60}$

Překlad románu se přes množství pozitivních prvků (jako dynamičnost a výraznost vyprávění, zachycení atmosféry války, specifiky vojenského života, bezprostředního humoru a stylu formulování dialogů) vyznačuje určitou nedotažeností a chybami. „Hulka nie

56 Tamtéž.

57 HULKA-LASKOWSKI, Paweł: Mój Żyrardów. Op. cit., s. 293.

58 HULKA-LASKOWSKI, Paweł: Czeski Rabelais - Cervantes. Powieść o Szwejku. Historia wojaka-aforysty. Wiadomości Literackie, 1927, č. 42, s. 1.

59 Tamtéž.

60 HAŠEK, Jaroslav: Przygody dobrego wojaka Szwejka podczas wojny światowej (Szwejk na froncie, Szwejk na tytach, Przeslawne lanie, Po bajecznym laniu). Warszawa: Rój, 1929-1931. Další doplněné a opravené vydání Warszawa, 1949, 1954, 1955, 1957. 
zawsze radzit sobie z transponowaniem wyrazeń idiomatycznych, popadat w przesadna dostowność $i$ zależność od originatu, btędnie ttumaczyt terminologię wojskowa. "61 Ve srovnání s originálem můžeme v Hulkově překladu zjistit přesun stylistické a umělecké kvality celého díla ve prospěch změn vyprávění, které je vždy přítomné v nesmrtelných anekdotách Josefa Švejka ${ }^{62}$ a je prezentací literární hodnoty díla. ${ }^{63}$

Podobně jako tomu bylo v případě Haškova „Švejka“, také prostřednictvím Literárních zpráv našel vydavatele pro svo̊j překlad trilogie Karla Čapka. Tento spisovatel ho nesmírně zaujal s ohledem na obecně lidskou, filozofickou problematiku svých děl. Hulka krátce po vydání poslední části Čapkovy tzv. noetické trilogie v Československu v roce 1934 zveřejnil článek s obsahem Hordubala, Povětroně a Obyčejného života. ${ }^{64}$ Nevěnoval se blíže umělecké, filozofické a psychologické vrstvě těchto děl. Omezil se na výzvu polským nakladatelům, v níž argumentoval mimoliterárními důvody: „[...] to rzecz na dwa, trzy wieczory kolejne“ ${ }^{65}$ Čapkova trilogie v Hulkově překladu vyšla v roce 1935 ve vydavatelství J. Przeworského. ${ }^{66}$ Její tři svazky zobrazující mnohostrannost a komplikovanost pravdy o člověku, obsahující ozvěny pragmatické filozofie, patří k nejvýznamnějším výsledkům Čapkovy prozaické tvorby. Popularizace Čapkovy trilogie byla významnou událostí v polsko-českých kontaktech během meziválečného dvacetiletí. Je třeba podtrhnout skutečnost, že právě překlad těchto tří titulů Karla Čapka byl jednou z nejlepších translátorských prací Hulky-Laskowského. „Przetransponowat on bowiem na jezzyk polski prawie wszystkie subtelności stylu originatu. Zachowat urok jasności i precyzji narracji, kameralność $i$ intelektualna gtebie rozważań psychologicznych, prostote opisów, nie pozbawionych jednak walorów poetyckich."67

Čapkovo dílo si v Hulkově překladu zakrátko získalo trvalé místo v polské kultuře. Mezi recenzenty trilogie můžeme najít i negativní postoje, svědčící o nepochopení intelektuálního obsahu Čapkova psaní. Například Józef Gołąbek se na základě představení nepřiliš důležité fabulační vrstvy trilogie domníval, že „Čapek wybitne miejsce w literaturze czeskiej zdobyt sobie gtównie przez doskonale dramaty, nie wynika z tego, aby go uważać za świetnego pisarza“ ${ }^{68}$ Častěji se objevovaly takové soudy, jaké po Hordubalovi přednesl Marian Jakóbiec na stránkách Roczniku Literackiego: „[...] dialogi bohatera powieści to arcydzieta

61 SIECZKOWSKI, A.: Literatura czeska i stowacka. In: Rocznik Literacki za rok 1955. Warszawa: Panstwowy Instytut Wydawniczy, 1956, s. 462-470.

62 Připomeňme in margine hlavního textu, že v Polsku existuje Klub přátel dobrého vojáka Švejka, což svědčí o stálé oblíbenosti tohoto díla u našich severních sousedů, byt mladší generace čtenářủ již tuto četbu z různých př́ičin nevyhledává.

63 Srov. MADANY, Edward: Uwagi o powieści J. Haška w zwiazku z recepcja „Szwejka“ w Polsce. Przegląd Humanistyczny, 1966, č. 3, s. 167-169.

64 HULKA-LASKOWSKI, Paweł: Trylogia Karola Čapka. Wiadomości Literackie, 1935, č. 9, s. 1.

65 Tamtéž.

66 ČAPEK, Karel: Hordubal. Přel. P. Hulka-Laskowski. Warszawa, 1935 (další vydání 1937, 1948, 1957); Meteor. Přel. P. Hulka-Laskowski. Warszawa, 1935 (další vydání 1948, 1957); Zwyczajne życie. Přel. P. Hulka-Laskowski. Warszawa, 1935 (další vydání 1948, 1957).

67 MADANY, Edward: Pawet Hulka-Laskowski... Op. cit., s. 149.

68 GOŁĄBEK, Józef: Literatury stowiańskie. Rocznik Literacki za rok 1935. Warszawa: Instytut Literacki, 1936 , s. $190-192$. 
psychologizmu literackiego. [...] Rdzeń filozoficzny optaca w ksiażce sowicie szabloność tematu, a gtębia myślowa waziutki nurt fabuty. "69

Po druhé světové válce se Hulka ještě jednou vrací k Čapkově tvorbě. Vybral si z ní starší spisovatelovo dílo poznamenané obavou z katastrofy vyvolané technizací života, dílo postulující každodenní filozofii pozitivní práce obyčejného člověka - Továrnu na absolutno (1922). Tento román byl v Hulkově překladu vydán až po jeho smrti. ${ }^{70}$

Překladatelská činnost Hulky-Laskowského obsahuje také překlady slovenské literatury, ale jen v malé míre. V roce 1935 si vybírá novelu slovenské spisovatelky Kristíny Rojové (1860-1936), tehdy oblíbené zejména v evangelických a protestantských kruzích. Tvorba rodačky ze Staré Turé se přes nevýraznou uměleckou hodnotu těšila značnou popularitou jako didakticky zaměřená literatura „pro nejmenší“. Autorka pocházející z významného evangelického rodu byla také známou aktivistkou slovenského abstinentního sdružení Modrý kríž. ${ }^{71}$ Hulka si z jejího díla vybral snad nejpovedenější práci Bez Boha na svete (1. vyd. 1893), i když šlo o naivní, selankovité, značně sentimentální vyprávění o horálkovi, ilustrující verš z Písma svatého „V té době jste byli bez Krista [...], bez naděje a bez Boha na světě" (Efez. 2, 12-13). Přetlumočení novely Rojové, údajně nejčetněji překládané slovenské autorky, vydal Hulka ve stejném lodžském nakladatelství, kde vycházely jeho překlady populárních didaktických prací Sylvanuse Stalla a Hulkovy vlastní příběhy pro děti a mládež. ${ }^{72}$

Byla to nicméně př́ležitostná překladatelská práce, nebot' ve Slezsku za Olzou, knize vydané o tři roky později, se setkáváme s autorovým svěřením, že slovenský jazyk neznal a blíže se s ním seznámil teprve během své cesty po českém Těšínsku, na kterou byl vyslán Instytutem Śląskim v Katovicích. Hulku-Laskowského tedy běžně nepočítáme mezi překladatele ze slovenštiny, nicméně jako diskutabilní se nám jeví názor Edwarda Madanyho, který můžeme, nebo naopak nemusíme přijmout, že „prawdopodobnie przektadu tego dokonat z jezyka czeskiego". Hulka se o překlad mohl pokusit přímo ze slovenštiny, která je češtině, ale ostatně i polštině velmi blízká. ${ }^{73}$ Dosud jsme nenašli ani doklad o tom, že by dílko Rojové Bez Boha na svete bylo v té době přeloženo do češtiny (mohl se s ním seznámit díky svým kontaktům v evangelických kruzích, ale to je tentokrát již z naší strany rovněž nepotvrzená domněnka, nebot’ autor na to téma, bereme-li v úvahu zejména jeho vzpomínky, nic přímo neříká, ani nějak nenaznačuje).

K dokreslení obrazu Hulkovy popularizátorské činnosti je třeba připomenout ještě dvě práce spojené s knižními překlady. V roce 1935 napsal krátkou přemluvu k polskému

69 JAKÓBIEC, Marian: Literatury stowiańskie. Rocznik Literacki za rok 1937. Warszawa, 1938, s. 187-195.

70 ČAPEK, Karel: Fabryka absolutu. Přel. P. Hulka-Laskowski. Katowice, 1947.

71 Srov.: http://zlatyfond.sme.sk/autor/218/Kristina-Royova; 30. 7. 2013

72 ROJOVÁ, Kristína: Bez Boga na świecie. Přel. P. Hulka-Laskowski. Łódź: Towarzystwo Wydawnicze „Kompas“, 1925; STALL, Sylvanus: O czym mtody cztowiek wiedzieć powinien. Přel. P. Hulka-Laskowski. Łódź: Towarzystwo Wydawnicze „Kompas“, 1927; HULKA-LASKOWSKI, Paweł: Od wiosny do wiosny. Ucieszna ksiażeczka dla grzecznych dzieci. Łódź: Towarzystwo Wydawnicze „Kompas“, 1925 (a další).

73 „Otworzyłem tomik [A. Žarnova] na chybil-trafil i zdumiałem się, jak dalece fonetyka i składnia slowacka bliska jest językowi polskiemu." 
vydání románu Ivana Olbrachta Nikola Šuhaj, loupežnik, který přeložil D. Oniszczyk. ${ }^{74}$ Psal v ní o přednostech díla, o realismu, s jakým autor vykreslil nahromaděné společenské, národnostní a náboženské konflikty na Podkarpatské Rusi, o mistrovském zobrazení protikladu mezi sny a touhami člověka po svobodě a tvrdou sociální pravdou. Své úvahy uzavřel názorem, že je to ,jedna z najpięknieszych ksiażek wspótczesnej literatury nie tylko czeskiej, ale w ogóle europejskiej “75. Proti tomuto Hulkově hodnocení opět vystoupil J. Gołąbek. Podobně jako v př́padě kritiky Čapkovy trilogie zaměřil se pouze na problematiku fabulace Olbrachtova románu. ${ }^{76}$ Jako protiváhu k Hulkově názoru podal příklady děl W. Łozińského Czarny Matwej, J. Rogosze Czarny Prokop a T. T. Jeże Rotutowicze, i když posledně jmenovaný titul pojednává o bulharských hajducích a nikoli o zbojnících z Tater (v př́ípadě Nikoly Šuhaje se ovšem děj románu odehrává v Karpatech, ale v tom nespatřujeme kardinální rozdíl v pojetí postav takového Jánošíka na straně jedné a Nikoly Šuhaje na straně druhé).

V roce 1937 byl díky iniciativě Velvyslanectví Československé republiky ve Varšavě ${ }^{77}$ vydán v překladu Witolda Bełzy soubor politických statí prezidenta Edvarda Beneše. ${ }^{78}$ Také tuto publikaci Hulka-Laskowski opatř̌il úvodem, v němž se s velkým uznáním vyjádřil o občanském a demokratickém postoji prvního prezidenta Československé republiky T. G. Masaryka. V podobném tónu ostatně psal o Masarykovi několikrát již dříve, nejen v Mém Žyrardově, ale také v časopisech. ${ }^{79}$ Spatřoval v něm a oceňoval vůdce myšlenkového pohybu na přelomu století, označeného v české historiografii za realismus.

Rok 1938 se zapsal do dějin česko-polských sousedských vztahů tragickým rozvířením národních animozit, které vedlo k těšínskému konfliktu. Na obou stranách hranice se záležitost Slezska stala nástrojem přiživování šovinistických nálad. Inspirovala vznik konjunkturálních publikací různého druhu, jejichž autoři své tendenční cíle halili do pseudovědeckého závoje. Polský slavista Edward Madany k nim z české strany řadí úvahy někdejšího majitele hospody v Komorní Lhotce Josefa (,Joži“) Vochaly Vývoj jazykové a národnostni otázky na Těšinsku (Frýdek, 1924) a Šlonzáci. Šlonzácká větev sjednoceného národa česko-slovenského (Frýdek, 1926). Na polské straně to měly být brožury Czesi. Studium historyczno-polityczne (Kraków, 1936), Cierpkie pobratymstwo (Warszawa, 1938) W. Filochowského. ${ }^{80}$ Problémy a křivdy obyvatel českého Těšínska hlásících se k polské národnosti byly uměle rozviřovány diplomatickými kruhy, což mělo posloužit jako

74 OLBRACHT, Ivan: Nikota Szuhaj zbójnik. Přel. D. Oniszczyk. Předmluva P. Hulky-Laskowského. Warszawa: Wyd. „Świat", 1935.

75 Tamtéž.

76 GOŁĄBEK, Józef: Literatury stowiańskie. Op. cit., s. 190-190.

77 O publikacích, jejichž vydání podpořilo Velvyslanectví Československé republiky ve Varšavě, píše Zdzisław Hierowski v knize Literatura czeska i stowacka w Polsce Ludowej. Katowice: Wydawnictwo „Śląsk“, 1966, s. 25.

78 BENEŠ, Edvard: Odrodzenie narodów. Přel. Witold Bełza. Warszawa: Instytut Wydawniczy „Renaissance“, 1937.

79 HULKA-LASKOWSKI, Paweł: Masaryk. Sygnały, 1937, č. 34, s. 4-5.

80 MADANY, Edward: Pawet Hulka-Laskowski... Op. cit., s. 151. 
bezpečnostní záklopka, jež by v polské společnosti ventilovala nálady nespokojenosti ze zahraniční politiky polské vlády. ${ }^{81}$

V této atmosféře se Hulka, vybídnut „Slezským ústavem“ v Katovicích, rozhodl odjet na Těšínské Slezsko, aby zjistil faktický stav situace Poláků na tomto území a napsal o tom knihu reportáží. Ujal se této mise nikoli proto, aby zvětšil počet tendenčních publikací, ale aby podal pravdivé svědectví, jehož hledání bylo typické pro všechny jeho práce. Slezskou problematikou se ostatně zabýval již mnohem dříve. V roce 1935 napsal pro Literární zprávy článek o polských tradicích této země, v němž vyjádřil přesvědčení, že „polityczne, gospodarcze i kulturalne interesy polsko-czeskie mogtyby $i$ powinny być daleko większe niz jest ich przeciwieństwo powstałe na tle sporu o Cieszyńskie“. ${ }^{82}$

Trasu své cesty po Těšínsku si zvolil takovou, aby obsáhla všechna místa, která uváděl Petr Bezruč ve sbírce Slezské pisně. Tehdy prý ještě byl pod vlivem sugestivní lyriky autora, kterého ovšem mylně považoval za slezského separatistu, a věřil $\mathrm{v}$ jeho žal nad zánikem „moraveckého“ živlu ve Slezsku ${ }^{83}$ Hulkův Ślask za Olza vznikl tedy z nejlepších úmyslů spisovatele, směřujících $\mathrm{k}$ uklidnění napětí, vzájemného vysvětlení zfalšovaných údajů o národnostních proporcích a otázkách teritoriálního vyrovnání. V úvodu knihy píše o svých mediačních záměrech mezi rozvášněnými stranami: „Bytbym szczéśliwy, gdyby mi los pozwolil doczekać chwili, w której mógtbym odwotać zarzuty postawione dziataczom czeskim na Zaolziu. [...] gdybym mógt przekreślić w swojej ksitżce stowo »czechizacja« i napisać: przyjaźń i braterstwo." ${ }^{44}$ Ve Slezsku za Olzou chtěl Hulka zaujmout postoj objektivního soudce. Zamýšlel svou práci opř́it o bohatý polský i český pramenný materiál. Uvedená literatura předmětu, kterou použil při psaní knihy, představuje až osmdesát devět položek. Mezi nimi se nacházejí práce polského historika Franciszka Popiołka a českého znalce dějin Slezska Aloise Adamuse. Nicméně ve výsledku se nechal Hulka unést spisovatelskou vášní, a tak namísto odborné publikace vznikla originální a impresivní reportáž - cestovní deník. $\mathrm{V}$ tom je její přednost i slabina. K pozitivům připočtěme neakademický, nekabinetní, ale živý, téměř antropologicko-etnografický přístup k tématu práce, na druhé straně $\mathrm{k}$ jejím negativům metodicky i metodologicky neujasněné komentáře $\mathrm{k}$ dějinám Slezska, k nimž patř́ jeho pokus o demaskování teorie o zpolštěných Moravcích, kterou údajně neformulovali vědci, ale konjunkturální aktivisté. Nicméně konkrétně práce zmíněného objektivního a nestranného historika Aloise Adamuse (1878-1964) byly dokonce natolik příznivé v hodnocení složité situace obyvatel tzv. Zaolzia (Záolží), hlásících se k polské národnosti, že byl nakonec označen za přehnaně propolsky orientovaného historika, musel odejít z Ostravy a pak profesně působil v severních Čechách. ${ }^{85}$

81 Srov. KOZEŃSKI, Jerzy: Czechostowacja w polskiej polityce zagranicznej w latach 1932-1938. Poznań: Instytut Zachodni, 1964.

82 HULKA-LASKOWSKI, Pawel: Kraina dla odkrywcy. Wiadomości Literackie, 1935, č. 40, s. 2.

83 HULKA-LASKOWSKI, Paweł: Ślqsk za Olza. Op. cit., s. 121.

84 Tamtéž, s. 5.

85 Srov. Adamus, Alois. In: MYŠKA, Milan a kol.: Biografický slovník Slezska a severní Moravy. Seš. 1. Red. Lumír Dokoupil - Ivo Barteček. Opava - Ostrava: Optys - Ostravská univerzita v Ostravě, 1993, s. 13-14. (Autorem hesla je Lumír Dokoupil.) 
Z hlediska literární historie je ve Slezsku za Olzou jednou nejzajímavějších kapitol Geografia Bezruča. ${ }^{86}$ Najdeme v ní hodnocení Slezských písni i četné překlady jednotlivých básní z této sbírky, které sice měly sloužit pouze jako citáty, ale nejsou zbaveny poetického kouzla a mají určitou uměleckou úroveň; to je důležité si uvědomit i proto, že do polštiny byly básně tohoto slezského barda zřídkakdy překládány a na Záolží měl básník mezi spisovateli a publicisty zavilé nepřátele ${ }^{87}$ (situace recepce Bezručova díla se později, zejména po roce 1989 , i v tomto ohledu změnila ${ }^{88}$ ).

Byl to také Alois Adamus, jenž ve své práci Po stopách Slezských písni Petra Bezruče (Brno, 1927) osvětlil historii Těšínského Slezska až do Bezručovy doby, kdy se rozhořely spory o to, zda se ve školách na česko-polském jazykovém pomezí má učit česky, nebo polsky. ${ }^{89}$ Bezručovy básně Kantor Halfar, Já a Domaslovice byly motivovány právě těmito spory a také konkrétními osudy učitelů (např. katolického kněze Jana Ježíška). Při pohledu z polské strany se tyto básně mohou jevit jako „protipolské“, ale s obdobně „protičeskými“ verši se lze setkat rovněž v polské poezii regionu (např. ve sbírce Pawła Kubisze Przednówek, 1. vyd. 1937). Až do roku 1848 se na těšínských školách učilo česky a německy (zároveň se smrtí Josefa II., který v roce 1782 spojil Moravu se Slezskem, dřívější germanizační tlak slábne). Mezi lid proniká moravské povědomí, zejména v západní části Těšínského Slezska, kde se obyvatelstvo cítí národnostně a kulturně spojeno s Moravou. Proti tomu stojí evangelíci, kteří se silně drží polské kultury. V důsledku zavedení konstitučního systému v rakouském mocnářství proniká polské národní obrození, vedené v této oblasti hlavně evangelíky, rychleji mezi lid. Katolíci v západní části regionu zůstávali při češtině, což v některých obcích vedlo ke sporům mezi obyvateli. Zároveň s převzetím školství státním aparátem v roce 1858 byl zaveden národní jazyk do škol podle jazykové hranice (stanovené úředně; rozdělení ne vždy odpovídalo skutečnosti). Petr Bezruč pak ve známé básni Já užil metaforu „zhasli“ jako symbolu zhášení světla ve školách v českých (moravsko-slezských) vesnicích v pohraničí. Odtud jeho rozhořčení a básnický obraz popolštění několika desítek tisíc obyvatel tohoto kraje.

Kniha Śląs za Olza vyvolala živý zájem recenzentů z různých středisek a regionů v Polsku, jejichž přehled podal Edward Madany. ${ }^{90}$ Gustaw Morcinek v úvodu své kritiky srovnal německou koncepci o Wasserpolácích s českou teorií o polonizovaných Moravcích. Dal také zapravdu Hulkovým úvahám o české kulturní vrstvě ve Slezsku. Pozitivně ocenil

86 HULKA-LASKOWSKI, Paweł: Ślask za Olza. Op. cit., s. 121-139.

87 MARTINEK, Libor: Pawet Kubisz kontra Petr Bezruč. K některým aspektiom literárního života polské národnostni menšiny v meziválečném obdobi. In: Setkání s druhým. Sborník příspěvků z VI. literární laboratoře konané v Hradci Králové 25.-26. 1. 2006. Hradec Králové: Gaudeamus, 2006, s. 54-70.

88 Jistou zásluhu na popularizaci Bezručova díla, zejména milostné lyriky, má i autor píšící tato slova, když zveřejnil nejprve článek Śladami Bezrucza (Śląsk 9, 2003, č. 10, s. 50-54), doplněný o zdařilé překlady Władysława Sikory Bezručových básní do polštiny, a poté i odbornou studii Śladami poezji Petra Bezrucza (In: Śląskie Miscellanea, sv. 17. Red. Krystyna Heska-Kwaśniewicz. Katowice: PAN-Oddział w Katowicach - Wydawnictwo Gnome, 2004, s. 115-125), která byla mj. zaměřena na topografii Slezských písní.

89 ADAMUS, Alois: Po stopách Slezských písní Petra Bezruče. Brno: Moravské kolo spisovatelů, 1927.

90 DYBCZYŃSKI, Tadeusz: Nowa Książka, 1938, č. 5, s. 264; JAZON, Z.: Sygnały, 1938, č. 53; JESIONOWSKI, Alfred: Prosto z mostu, 1938, č. 23, s. 5; KUBISZ, Paweł: Ateneum, 1938, č. 4-5, s. 731-733; MORCINEK, Gustaw: Myśl Polska, 1938, č. 9, s. 4. 
Hulkovu intenci i výsledek jeho práce: „Dobrze, że napisat to pisarz i publicysta tej miary, jakim jest Hulka. Wszak to cztowiek, który taczy w sobie to, co najszlachetniejsze w kulturze czeskiej i polskiej. Który stworzony na to, by być tacznikiem między kultura polska i czeska. "91 Alfred Jesionowski zaujal vůči Slezsku za Olzou kritičtějš́i postoj. Vzal v úvahu fakt, že Polsko nemělo dostatek jasných a ucelených informací o problematice tzv. Záolží, takže autorovi vytkl zaujetí osobního postoje v představení situace Poláků za Olzou. Od Hulkovy práce očekával suché, vědecké pojetí. Místo toho v ní našel vlastní autorskou linii, podle níž Hulka vyselektoval materiál získaný pozorováním. Z četby textu získal dojem, že spisovatel se ve vztahu ke své knize podrobil „preventivní cenzuře“: „Widaje mi sie, że metoda opracowania problemu polskiego na Zaolziu nie byta najodpowiedniejsza. Forma notatnika z podróży, przestrzegana aż nadto skrupulatnie, stwarza pewien chaos w ujeciu materiatu rzeczowego, utrudnia zorientowanie się $w$ sprawie najważniejszej, to jest w przszłości i terażniejszości Polaków na Zaolziu. Zwtaszcza ta terażniejszość dochodzi do gtosu zbyt dyskretnie, odnosi się czasem wręcz wrażenie, jakby ksiażka ulegta jakiejść cenzurze prewencyjnej." "92 Básník a publicista Paweł Kubisz, který na českém Těšínsku neboli Záolží žil a tvořil, se v recenzi knihy Slezsko za Olzou pochvalně zmínil o autorově nestrannosti a objektivnosti ke zvolenému tématu, k němuž si Hulka zachoval potřebný odstup, a ocenil, že se v knize neobjevuje žádná politická tendence vůči slovanským Čechům. Neopomenul zkritizovat osobnost Petra Bezruče, který se přičinil ke zdůvodnění čechizace polských obyvatel českého Těšínska, zkritizoval sbírku Slezské pisně za jejich spornou uměleckou pravdu, která je pouze politickou lží, a zejména připomněl některé básníkovy názory z knihy Moravská zem a moravská ř Republika před svatým Petrem (1923), které chybně, dá se říci i tendenčně interpretoval ${ }^{93}$ : „W broszurze tej Bezrucz niedwuznacznie potepia t. zw. czeskostowacka państwowość jako objaw rzadzacy $i$ suwerenny $i$ domaga się autonomii nie tylko dla ziem morawskoślaskich lecz także dla Stowacji." ${ }^{94}$ Podobně nenechal Kubisz suchou nit na Łysohorském, v té době autorovi dvou sbírek básní v tzv. laštině, jemuž dokonce vytýká, že jeho lašské nářečí (v tomto případě šlo o pokus vytvořit spisovnou laštinu na nářečním základě) je nástrojem čechizace, „skoro w wierszach tych spotykamy nawet mnóstwo takich czechizmów, którymi w ogóle nie postuguje się lud ślaski z wspomnianych terenów“. ${ }^{95}$ Kubisz se také značně demagogicky vyjádřil k politickým postojům tehdy levicově orientovaného autora ${ }^{96}$ sbírek Śpiwajuco piaść (1932) a Htos hrudy (1935): „Poezja Eysohorskiego w dotychczasowym stanie, jest raczej

91 MORCINEK, Gustaw: Ślask za Olza. Myśl Polska. Op. cit.

92 JESIONOWSKI, Alfred: Śladami pieśni Petra Bezruča. Prosto z mostu. Op. cit.

93 Bezručova brožura je zaměřena čistě filologicky, s politikou nic společného nemá, jde o Bezručovu obranu moravských jazykových tvarů. P. Kubisz jí připisoval př́liš velkou váhu v kontextu soužití etnik ve Slezsku a problematiky slezského separatismu. Naopak Petr Bezruč se nikdy nevyslovil pro nějakou „autonomii“ jako P. Kubisz, navazující před válkou kontakty se slovenskými nacionalisty pod vedením Andreje Hlinky. Nanejvýš byl pro scelení Těšínska po obou stranách řeky Olzy a pro jeho př́íslušnost do Koruny České, kam historicky patřilo od doby vlády Jana Lucemburského. (U Bezruče tedy převážil názor historický nad etnografickým v otázce dělení Těšínského Slezska, který ovšem česká historiografie zastává dodnes.)

94 KUBISZ, Paweł: Pawet Hulka-Laskowski: „Śląsk za Olzą“. Ateneum, 1938, č. 4-5, s. 732.

95 Tamtéž.

96 Łysohorského mládí, studium, zahraniční cesty, styk s proletářským prostředím a v neposlední řadě jeho tvorba sama, jíž předcházelo období studia lašského folkloru v Beskydech, přivedly básníka na politickou 
urabianiem orientacji sowieckiej na terenach ślaskich w Czechostowacji i nawet dosyć przejrzyście inklinuje do wytworzenia atmosfery czy legendy do stworzenia ślaskiej republiki radzieckiej. ${ }^{~} 97 \mathrm{Ku}-$ bisz při té příležitosti přiživuje mýtus o tom, že slezský lid „w mowie swej zachowat pra-polski jezyk Reja i Modrzewskiego"98 Těšínské nářečí sice zachovalo prvky, které se v dnešní spisovné polštině nevyskytují, jako například aorist (byłech, widziołech, jechołech atp., místo byłem, widziałem, jechałem), avšak aoristy se vyskytují také ve slezských nářečích (hornoslezském a opolském) a v některých malopolských nářečích a na nějakou starobylost těšínského nářečí z těchto jazykových jevů nelze usuzovat. Kubisz se rovněž mylně domnívá, že Łysohorského pokus o vytvoření spisovaného lašského jazyka pro obyvatele českého Slezska je důkazem toho, „iz nie tylko Ślask Cieszyński posiada swe wytaczne, dawne $i$ ciagte prawo do polskości $i$ naodwrót, lecz że również $i$ takie tereny jak Frydeckie $i$ w wielkiej części Opawskie i Huczyńskie nie sa w żadnej mierze pozbawione tych praw ${ }^{.99} \mathrm{~V}$ recenzi Kubisz znovu přiživuje své přesvědčení, že by slezský regionalismus měl být vytvářen na způsob regionalismu podhalanského, z nepochopení této neuskutečněné myšlenky obviňuje kulturní politiku Horního Slezska, nebot „Katowice stale sprawe te przeoczaja czy nie chca jej docenić - przysztość pokaże czy stusznie“. ${ }^{100}$ Budoucnost pak ukázala, že ve třicátých letech 20. století byla taková tendence již anachronismem. ${ }^{101}$ Konečně ho mrzí, že mezi Hulkou-Laskowským anketovanými osobami na českém Těšínsku (v polské publicistice na tzv. Zaolziu) nebyl nikdo z mladší generace (k níž se Kubisz, narozený v roce 1907, počítal). Jelikož se o tom autor nikde nezmiňuje, byly mu tedy informace podány jednostranně. Kubisz přiznává, že stará polská tradice ve Slezsku byla pěkná, „lecz niekiedy wnuki i spadkobiercy tej tradycji - czyli dzisiejsze starsze spoteczeństwo polskie na Ślasku Zaotzańskim - w swej dziatalności spotecznej bardzo mato upodabniaja sie do dawnych bezkompromisowych sposobów walki" 102 .

Koncem šedesátých let 20. století se k Hulkově knize ještě vrací Zdzisław Hierowski ve své syntéze slezského písemnictví. ${ }^{103}$ Podle katovického kritika autor místy formuluje příliš povrchní soudy, někdy nadmíru podléhá jednostranně zaměřené literatuře, ale v polsko-československém sporu konce třicátých let 20. století šlo o ojedinělý hlas zdravého rozumu. Autor vede polemiku - jak se dalo očekávat - se Slezskými písněmi Petra Bezruče, které uznává z hlediska jejich básnické hodnoty a v nich obsaženého sociálního protestu, ale má výhrady vůči básníkovu pojetí národnostní problematiky. (Podobně vede spor s pracemi Joži Vochaly.) Hierowski se nicméně domnívá, že se Hulka-Laskowski sna-

levici, ke komunistickému hnutí a k poznání marxizmu. V létě roku 1934 navázal kontakty s marxistickým kritikem Bedřichem Václavkem. Členem KSČ se Łysohorsky nikdy nestal.

97 KUBISZ, Pawel: Pawet Hulka-Laskowski: „Śląsk za Olzą“. Op. cit., s. 732.

98 Tamtéź, s. 731.

99 Tamtéž, s. 732.

100 Tamtéž, s. 733.

101 Srov. MARTINEK, Libor: Polská literatura českého Těšnska jako regionální literatura a jeji pozice na styku kultur. In: MARTINEK, Libor: Polská literatura českého Těšínska po roce 1945. Op. cit., 2004, s. 13-28.

102 KUBISZ, Pawel: Pawet Hulka-Laskowski: „Śląsk za Olzą“. Op. cit., s. 733.

103 Srov. HIEROWSKI, Zdzisław: Życie literackie na Ślasku w latach 1922-1939. Katowice: Wydawnictwo „Śląsk“, 1969, s. 283-284. 
žil představit české Těšínsko, respektive Záolží, jako místo, které by mohlo být mostem přátelství mezi oběma národy, zatímco se stalo ohniskem národnostních třenic.

Kniha Slezsko za Olzou nepředstavuje nějakou výjimku v tvorbě Hulky-Laskowského, která by přispívala ke sblížení polského a českého národa. Naopak. Je dalším svědectvím autorova pozitivního a přátelského postoje $\mathrm{k}$ Čechům. Je ještě jedním a obzvláště bolestným svědectvím o důsledně realizované linii hledání a odhalování pravdy, i kdyby byla nepř́ijemná. „Dziatalność pisarska Laskowskiego na tym polu, obejmujaca bez mata cate pótwiecze, przedstawia więc obraz monolityczny, $i$ w kontaktach literackich polsko-czeskich dwudziestolecia miedzywojennego jest zjawiskiem bardzo rzadkim. "104

Paweł Hulka-Laskowski byl skutečně oním mostem, jenž měl být postaven mezi dvěma tak blízkými si národy. Zapomněl však na to, že po mostu se také šlape (a někdy i okovanými botami) a že mosty se při ústupu vyhazují do povětří. Věrný humanitním ideálům svého velkého vzoru, prezidenta Tomáše Garrigue Masaryka, doufal ve Slezsku nad Olzou, že by stačilo obrátit se na rozumné představitele vlády, kteří by mohli zlepšit situaci obyvatel na českém Těšínsku: „Gdy po wędrówkach swoich po Zaolziu wspominatem ludzi, którzy ze tzami w oczach opowiadali mi o swoich niedolach w zwiazku z akcja czechizacyjna, pomyślatem, $\dot{z}$ e chyba nic prostszego, jak zwrócić się do tego męza [T. G. Masaryka], rozporzadzajacego wielkim autorytetem, aby uczynit koniec walkom tak smutnym $i$ zbędnym zarazem. Wydawato mi sie niestychanie prostym, że tam, gdzie dwa pokrewne narody musza ze soba sasiadować tak blisko $i$ mieszkać w ramach tej samej państwowości, porozumienie przy odrobinie dobrej woli musi być rzecza bardzo tatwa. "105 Bohužel příslovečná špetka dobré vưle se neprojevila ani na jedné ze znepřátelených stran, a tak „velká historie“ po Mnichovu 1938 a hitlerovském vpádu do Polska (Těšínské Slezsko se nestalo součástí Protektorátu, ale bylo přivtěleno k Říši) vtrhla s nebývalou krutostí také do života běžných obyvatel tohoto regionu - bez ohledu na českou nebo polskou národnost.

Osvobození od fašismu označil Hulka za „návrat člověka“. Spisovatel se po válce také dočkal četných poct. Jako první ho navštívila delegace Kościuszkovců, která mu vyslovila svůj obdiv a úctu, v březnu 1945 obdržel státní cenu za „wieloletnia, żywa, uczciwa i nieskazitelnie demokratyczna dziatalność literacka“. Během prvních měsíců roku 1945 onemocněl na zánět žlučníku, což mělo za následek zhoršení jeho zdravotního stavu. Hulkovi přátelé se mu snažili zajistit pobyt na Těšínském Slezsku, po kterém se mu velmi stýskalo. V té době ho osobně navštívil tehdejší ministr zahraničních věcí Wincenty Rzymowski, aby ho pověřil účastí na vytýčení sporné polsko-české hranice na Těšínsku. Oslaben nemocí, přesto naplněn obavami a zároveň radostí odcestoval na Těšínské Slezsko, které nazýval „otčinou své duše“. Zároveň byl znechucen chováním svých žyrardovských spoluobčanů, kteří jako mstu za okupační křivdy obraceli vniveč všechno, co bylo německé, včetně evangelického hřbitova ( $\mathrm{z}$ nedostatku základních informací). V Těšíně měl Hulka řadu přátel mezi evangelíky, kteří se tam těšili úctě, a tím spíš nikdo nenarušil věčný odpočinek zemřelých této víry. Přestože po delší dobu regeneroval své síly ve vile Belveder ve středisku Wiśla-Głębice a dokončil román o římském básníkovi Catullovi Warkocz

104 MADANY, Edward: Pawet Hulka-Laskowski... Op. cit., s. 153.

105 HULKA-LASKOWSKI, Paweł: Ślask za Olza. Op. cit., s. 153. 
Bereniki a román o Kristovi Ostatni totr, s ohledem na špatný zdravotní stav se musel přemístit do nemocnice v Těšíně, kde zemřel na mozkovou mrtvici 29. 10. 1946.

Během pobytu na Těšínském Slezsku psal Hulka pro Ministerstvo zahraničních věcí PR zprávy o polsko-českých vztazích, spolupracoval s novinami (mj. s Trybunou Robotniczou) a časopisy. V nemocnici napsal svůj poslední článek Najpiękniejszy kraik świata, v němž vyjádřil svou hlubokou spojitost s Těšínským Slezskem. Manifestačního pohřbu Pawła Hulky-Laskowského se zúčastnilo kolem sedmi tisíc osob, včetně oficiální delegace z Žyrardowa. Spisovatelův hrob se nachází na evangelickém hřbitově v Těšíně. Tam také odpočívá jeho manželka Kazimiera, která zemřela v roce 1976. Osud tomu chtěl, že literárním testamentem Pawła Hulky-Laskowského se stal Ksieżyc nad Cieszynem. Po jeho smrti vyšlo v tisku mnoho prohlášení vysoce oceňujících žyrardovského rodáka, projevujících rovněž lítost nad tím, že úmrtí spisovatele je ztrátou nejen pro Polsko, ale také pro evropskou religionistickou a humanistickou literaturu. Češi v Hulkovi-Laskowském ztratili neúnavného iniciátora dobrých sousedských česko-polských vztahů, překladatele kvalitních děl české literatury a propagátora české kultury v Polsku.

Na závěr připomeňme, že v roce 1996 a pak v roce 2001 se u příležitosti jubileí narození a úmrtí Pawła Hulky-Laskowského konala celá řada akcí k uctění památky nejvýznamnějšího žyrardovského rodáka a autor Měsice nad Těšinem byl připomenut i v polském Těšíně. ${ }^{106}$ Náš článek si kromě literárněvědného aspektu kladl za cíl připomenout čtenářum dílo a aktivity tohoto $\mathrm{u}$ nás pozapomenutého polského spisovatele $\mathrm{s}$ českými kořeny, spojovaného především s překladem Haškových Osudi̊ dobrého vojáka Švejka za světové války do polštiny.

\section{doc. PhDr. Libor Martinek, Ph.D.}

Ústav bohemistiky a knihovnictví

Filozoficko-přírodovědecká fakulta, Slezská univerzita v Opavě

Masarykova tř. 37, 74601 Opava, Česká republika

martinek.libor@centrum.cz

Instytut Filologii Słowiańskiej Uniwersytetu Wrocławskiego

Pocztowa 9, 53-313 Wrocław, Polska

libor.martinek@uwr.edu.pl

$106 \mathrm{O}$ všech těchto oceněních a akcích různého druhu (včetně odborné konference) zde není možné podrobněji referovat, odkazujeme proto opět na internetové stránky obou měst - Žyrardova a Těšína, zejména na text Pawet Hulka Laskowski 1881-1946. Pisarz, najwybitniejszy żyrardowianin (připravil Wydział Informacji i Promocji Miasta Urzędu Miejskiego w Żyrardowie). 